\title{
PENGEMBANGAN EKSTRAKURIKULER PAI: Studi Kasus SMAN I Mataram, NTB
}

\author{
Suprapto \\ Peneliti Puslitbang Pendidikan Agama dan Keagamaan \\ E-mail: suprapto.litbang@yahoo.com
}

\begin{abstract}
The objectives of this study are to determine: 1) efforts the schools have made in developing the students' religious extracurricular activities internally while ascertaining the types of religious extracurricular activities at schools, 2) influencing factors to the implementation of such extracurricular programs. This study was conducted in SMA Negeri 1 Mataram, West Nusa Tenggara, during which a descriptive analytic method was used and the data were collected through questionnaires, interviews in addition to observation and manuscript study. The results show that extracurricular activities conducted in the target school involved quite a diverse religious activity which includes: Holy Qur'an recitation at the beginning of each class, midday prayer in congregation, congregated prays to open and conclude each class, congregated Friday sermon, Qurban sacrifice festivity, and organization of varied activities commemorating the Islamic Holidays (PHBI)" and more. In addition, two major reasons had influenced the students' participation in these extracurricular programs, which are classified as (a) internal and (b) external factors. The first includes spiritual, social, and personal motives. And the second relates to these very extracurricular activities ranging from the program, material, method, tutor, to teacher's stimulus.
\end{abstract}

Key Word: Extracurricular, Islamic religious education

\section{Abstrak}

Tujuan penelitian ini adalah untuk mengetahui: 1) upaya-upaya yang dilakukan oleh sekolah dalam mengembangkan aktivitas ekstrakurikuler keagamaan siswa di sekolah, mengetahui jenis aktivitas ekstrakurikuler keagamaan di sekolah, 2) faktor-faktor yang mempengaruhi pelaksanaan program ekstrakurikuler keagamaan siswa di sekolah. Lokasi penelitian dilakukan di SMA Negeri 1 Mataram, Nusa Tenggara Barat. Penelitian ini bersifat deskriptif analitik, dengan teknik pengumpulan datanya melalui angket, wawancara, observasi dan studi dokumen. Hasil penelitian menunjukan bahwa kegiatan ekstrakurikuler yang dilakukan di sekolah sasaran penelitian terdapat cukup beragam kegiatan keagamaan seperti: membaca Al-Qur'an pada awal jam pelajaran, sholat dzuhur bersama, berdo'a bersama-sama dalam memulai dan mengakhiri pelajaran, sholat jum'at bersama, pemotongan hewan Qurban, serta menyelenggarakan kegiatan "pada peringatan hari-hari besar Islam (PHBI)" dan lain-lain. Selain itu terdapat dua faktor utama yang berpengaruh terhadap keikutsertaan siswa dalam program ekstrakurikuler keagamaan, yaitu; (a) internal, dan (b) eksternal. Faktor internal, antara lain; motif keagamaan, motif sosial, dan motif pribadi. Sedangkan faktor eksternal, berkenaan dengan kegiatan ekstrakurikuler keagamaan itu sendiri, seperti; program, materi, metode, pembimbing, dan dorongan guru.

Kata Kunci: Ekstrakurikuler, Pendidikan Agama Islam

Naskah diterima 27 Mei 2013. Revisi pertama, 22 Juni 2013. Revisi kedua, 10 Juli 2013 dan revisi terahir 3 Agustus 2013. 


\section{PENDAHULUAN}

\section{Latar Belakang Masalah}

Hakekat kemerdekaan bangsa Indonesia seperti tercantum dalam Pembukaan Undang Undang Dasar 1945 adalah meningkatkan kesejahteraan umum dan mencerdaskan kehidupan bangsa. Untuk mencapai tujuan tersebut pemerintah menetapkan pendidikan sebagai salah satu sasaran pokok program pembangunan. Melalui pendidikan kualitas sumber daya manusia diharapkan dapat ditingkatkan. Pendidikan harus secara utuh mengembangkan seluruh potensi kepribadian anak, baik pengembangan aspek afektif, seperti ketaqwaan, budi pekerti yang luhur, akhlak mulia, demokrasi, kreatif dan mandiri. Aspek kognitif atau kecerdasan intelektual, aspek psikomotor atau keterampilan dan aspek jasmani siswa.

Peran pendidikan ini akan semakin besar artinya dalam menghadapi era globalisasi yang makin makin berat, utamanya dalam mempertahankan jati diri bangsa. Ketahanan pribadi makin menjadi penting karena dalam proses pendidikan terjadi peningkatan kemampuan intelektual termasuk penguasaan, penerapan, dan pengembangan ilmu pengetahuan serta teknologi tanpa menghilangkan jati diri anak didiknya. Pendidikan formal, non formal serta pendidikan informal merupakan suatu kesatuan pendidikan yang bersifat integratif alam menanamkan nilai-nilai jati diri bangsa tersebut.

Sekolah sebagai suatu sistem memiliki tiga aspek pokok yang sangat berkaitan erat dengan mutu sekolah, yakni: proses belajar mengajar, kepemimpinan dan manajemen sekolah, serta kultur sekolah. ${ }^{1}$ Dalam kegiatan pembelajaran sekolah sangat penting dan strategis dalam pembinaan siswa, baik melalui proses belajar mengajar maupun melalui kegiatan kokurikuler dan ekstrakurikuler.

${ }^{1}$ Zamroni., 2000. "Paradigma Pendidikan Masa Depan". Jakarta: Bigraf Publishing, h. 148
Usia SLTA adalah usia dalam pertumbuhan fisik dan perkembangan mental individu menunju kedewasaan sehingga mempengaruhi perilaku mereka sehingga menjadi makin aktif, kreatif untuk melakukan eksperimen-eksperimen dalam kehidupannya guna mencari keseimbangan hidup. Upaya perwujudan keseimbangan dan perkembangan hidup adalah usaha pencarian identitas diri. Dalam pencarian identitas diri ini, individu sangat rentan sekali terhadap pengaruh diluar dirinya. Masa pencarian identitas diri ini merupakan masa yang sangat strategis dan kritis dalam kehidupan setiap individu. Strategis karena individu akan lebih mudah menerima pembaruan untuk meningkatkan potensi dirinya secara positif, dan kritis, karena ia akan mengalami goncangan atau ujian sehingga dapat mengakibatkan ketidakseimbangannya dalam kehidupan.

Upaya untuk mewujudkan wawasan Wiyatamandala antara lain dengan menciptakan sekolah sebagai masyarakat belajar, pembinaan Organisasi Siswa Intra sekolah (OSIS), kegiatan kurikuler, kokurikuler, dan ekstra-kurikuler, serta menciptakan suatu kondisi untuk mengasah kemampuan dan ketangguhan yakni memiliki tingkat keamanan, kebersihan, ketertiban, keindahan, dan kekeluargaan yang mantap

Nilai-nilai positif yang dianut dan menjadi idola bagi remaja, ada yang baik seperti menunjukkan prestasi sekolah, pekerja seni, olah raga, dan lain sebagainya. Namun demikian ada juga tindakan dan perilaku yang seringkali menjerumuskan anak muda kedalam kehidupan yang tidak diredhoi Allah seperti pergaulan bebas, perjudian, penodongan, perampokan, narkoba, tawuran pelajar, dan pakaian yang tidak menutupi aurat.

Semua masalah yang berkenaan dengan prilaku menyimpang remaja akhirnya memunculkan pertanyaan ada apa dengan lembaga pendidikan. Peranan dan efektivitas sekolah bagi pengembangan nilai spiritual anak didik makin dipertanyakan. Dengan asumsi jika proses pendidikan agama berjalan 
dengan baik, maka perilaku anak didik dan masyarakatnya akan lebih baik.

Banyak upaya yang telah dilakukan oleh Kementerian Agama dalam meningkatkan kualitas pendidikan agama diantaranya seminar, loka karya, peningkatan kompetensi guru agama, pembinaan akhlak langsung terhadap siswa, dsb. Disamping itu berbagai cara pendekatanpun telah dilakukan, baik yang bersifat persuasif maupun militeristik seperti penandatanganan ikrar, pembinaan pelajar bermasalah, pelajar siaga, pesantren kilat dan bahkan Kanwil Depdiknas DKI Jakarta bekerja sama dengan pihak keamanan telah menyelenggarakan pendidikan khusus bagi siswa yang tergolong nakal, yang dikenal dengan nama Sekolah Kodim. Namun semua upaya tersebut belum menunjukkan hasil yang maksimal karena masih banyak ditemukan prilaku dan akhlak sebagian remaja semakin jauh menyimpang dari tuntuan agama.

Banyak faktor penyebab terjadinya penurunan akhlak remaja, antara lain adalah orang tua yang lalai melakukan tugas, dan kewajibannya sebagai pendidik, pembimbing dan pelindung anak; orang tua kurang memberikan perhatian dan kasih sayang serta jarang melakukan komunikasi dengan anak. Namun demikian hasil studi Pusat Penelitian Depdikbud menunjukkan bahwa siswa yang tergolong baik ternyata berasal dari sekolah yang kegiatan ekstrakurikulernya berjalan dengan baik, tidak terlibat tawuran dan kenakalan remaja lainnya.

\section{Rumusan Masalah Penelitian}

Berdasarkan latar belakang di atas perlu dilakukan satu kajian yang mendalam dan komprehensif, melalui penelitian yang dapat menjawab pertanyaan tentang:

1. Bagaimana upaya sekolah dalam mengembangkan aktivitas ekstra kurikuler keagamaan siswa?

2. Apa saja aktivitas ekstrakurikuler ekstra kurikuler keagamaan siswa di sekolah?
3. Faktor-faktor apa saja yang berpengaruh terhadap pelaksanaan program ekstrakurikuler keagamaan siswa di sekolah?

4. Bagaimana kerjasama sekolah, orang tua dan lembaga keagamaan dalam penyelenggaraan kegiatan ekstra kurikuler keagamaan siswa di sekolah?

\section{Tujuan}

Penelitian ini bertujuan untuk mengetahui dan memberikan gambaran yang utuh mengenai:

1) Upaya-upaya yang dilakukan oleh sekolah dalam mengembangkan aktivitas ekstrakurikuler keagamaan siswa di sekolah.

2) Jenis aktivitas ekstrakurikuler keagamaan di sekolah.

3) Faktor-faktor yang mempengaruhi pelaksanaan program ekstrakurikuler keagamaan siswa di sekolah

4) Kerjasama yang dilakukan oleh sekolah, orang tua dan lembaga keagamaan dalam pelaksanaan kegiatan ekstrakurikuler keagamaan siswa di sekolah

\section{Kegunaan Penelitian.}

Hasil penelitian ini diharapkan dapat memberikan gambaran tentang kegiatan ekstrakurikuler keagamaan siswa Islam di sekolah. Selain itu informasi tersebut diharapkan dapat dijadikan bahan masukan kepada pihak yang berwenang, khususnya Kementerian Agama RI, guna dijadikan sebagai bahan pertimbangan dalam membuat kebijakan, dalam rangka mengoptimalkan peran guru agama untuk mengembangkan kegiatan ektrakurikuler siswa di sekolah.

\section{Kajian Teoretik}

Kegiatan ekstrakurikuler adalah kegiatan yang dilaksanakan di sekolah atau di lingkungan masyarakat untuk menunjang program pengajaran. Selain itu, Suharsimi 
Arikunto mendefinisikan ekstrakurikuler sebagai kegiatan tambahan diluar struktur program yang pada umumnya merupakan program pilihan. ${ }^{2}$ Pendapat lain mengatakan bahwa ekstrakurikuler merupakan wadah pembentukan karakter siswa dalam lingkungan sekolah yang bertujuan untuk mengembangkan jiwa kepemimpinan dan kemampuan sosial melalui berbagai aktivitas baik yang terkait langsung maupun tidak langsung dengan materi kurikulum. ${ }^{3}$ Senada dengan hal tersebut ekstrakurikuler diartikan sebagai kegiatan pendidikan di luar mata pelajaran dan pelayanan konseling untuk membantu pengembangan peserta didik sesuai dengan kebutuhan, potensi, bakat dan minat mereka melalui kegiatan yang secara khusus diselenggarakan oleh pendidik dan tenaga kependidikan yang berkemampuan dan berwenang di sekolah/madrasah. ${ }^{4}$ Untuk itu maka sekolah harus dapat memfasilitasi berbagai kegiatan non akademik yang mengarah kepada pembentukan kepribadian dan kepemimpinan peserta didik. Atau dengan kata lain sekolah sebagai instansi yang selama ini dipercaya untuk mendidik anak-anak dan remaja dapat mengambil peran membantu remaja mengisi waktu luangnya dengan kegiatan positif. Sekolah perlu memberikan kesempatan melaksanakan kegiatankegiatan non akademik melalui perkumpulan penggemar olah raga, kesenian dan lainnya untuk membantu remaja menyelesaikan tugas perkembangannya. ${ }^{5}$

Inti kegiatan ekstrakurikuler adalah untuk mengembangkan kepribadian peserta didik. Dalam mata pelajaran pendidikan agama Islam, pengembangan kepribadian peserta didik dapat dilakukan melalui kegiatan ekstrakurikuler keagamaan. Oleh Karena itu, pembentukan kepribadian yang matang merupakan

${ }^{2}$ Suharsimi Arikunto. 2006. Prosedur Penilaian Suatu Pendekatan Praktik. Jakarta: Bumi Aksara, h. 47

${ }^{3}$ http://smanbergas.sch.id,2008:online

${ }^{4}$ http://ariefyuri.blogspot.com/2009/03/ pentingnya-kegiatan-ekstrakurikuler.html

${ }^{5}$ Ali M. Asrori. 2008. Psikologi Perkembangan Peserta didik. Jakarta: Bumi Aksara, h. 170 tujuan utama dari kegiatan ekstrakurikuler. Pengembangan kepribadian yang matang dalam konteks pengembangan kegiatan ekstrakurikuler tentunya dalam tahap-tahap kemampuan peserta didik. Mereka dituntut untuk memiliki kematangan dan keutuhan dalam lingkup dunia hunian mereka sebagai anak yang tengah belajar. Mereka mampu mengembangkan bakat dan minat, menghargai orang lain, bersikap kritis, terhadap suatu kesenjangan, berani mencoba hal-hal positif yang menantang, peduli terhadap lingkungan, sampai pada melakuan kegiatan-kegiatan intelektual dan ritual keagamaan.

Dalam konteks Pendidikan Nasional, semua cara, kondisi, dan peristiwa dalam kegiatan ekstrakurikuler sebaiknya diarahkan pada kesadaran nilai-nilai universal agama sekaligus pada upaya pemeliharaan beragam. Karena itu, padbeberapa sekolah, program ekstrakurikuler dikembangkan secara integral baik dalam pengalaman fisik maupun dalam pengalaman psikis. Model-model pengembangan kegiatan ekstrakurikuler hendaknya selalu diarahkan secara integral untuk mencapai tahapantahapan perkembangan kepribadian peserta didik yang matang.

Kegiatan ekstrakurikuler dapat dikembangkan dalam beragam cara dan isi. Penyelenggaraan kegiatan yang memberikan kesempatan luas kepada pihak sekolah, pada gilirannya menuntut pimpinan sekolah, guru, siswa, dan pihak yang berkepentingan lainnya untuk secara kreatif merancang sejumlah kegiatan sebagai muatan kegiatan ekstrakurikuler. Muatan-muatan kegiatan yang dapat dirancang oleh guru/ pembina program kegiatan keagamaan. Program ini bermanfaat bagi peningkatan kesadaran moral beragama peserta didik. Dalam konteks Penidikan Nasional hal itu dapat dikembangkan sesuai dengan jenis kegiatan yang terdapat dalam lampiran Kepmen Diknas No. 125 /U/ 2002 antara lain: pesantren kilat, tadarus, shalat berjamaah, shalat tharawih, latihan dakwah, baca tulis Al-Qur'an, pengumpulan zakat, dll. 
Kegiatan ektrakurikuler berfungsi untuk: mengembangkan kemampuan dan kreativitas peserta didik sesuai dengan potensi, bakat dan minat mereka., mengembangkan kemampuan dan rasa tanggung jawab sosial peserta didik, mengembangkan suasana rileks, menggembirakan dan menyenangkan bagi peserta didik yang menunjang proses perkembangan dan mengembangkan kesiapan karir peserta didik.

\section{Metodologi}

Penelitian ini dilakukan di SMA Negeri 1 Mataram, Nusa Tenggara Barat. Penelitian ini bersifat deskriptif analitik, yaitu data dideskripsikan dengan menggunakan statistik deskriptif, dan dimaknai secara mendalam berdasarkan perspektif emic, yaitu penyajian data secara alamiah tanpa melakukan suatu manipulasi atau perlakuan terhadap subjek yang diteliti. Unit analisis aktivitas ekstrakurikuler keagamaan adalah siswa.

Teknik pengumpulan data, diperoleh melalui: (1) penyebaran kuesioner (angket) kepada siswa, (2) wawancara mendalam terhadap kepala sekolah, guru pembina kesiswaan, guru agama, (3) observasi terhadap lingkungan sekolah, sarana-prasarana dan fasilitas kegiatan ekstrakurikuler keagamaan yang ada disekolah tersebut, dan (4) studi dokumen, yaitu peneliti berusaha mengkaji dokumen yang ada di sekolah berkenaan dengan aktivitas keagamaan sekolah.

Teknik Analisis Data dinalisis secara kuantitatif dan kualitatif. Secara kuantitatif menggunakan statistik deskriptif. Dengan cara ini diperoleh gambaran akan kecendrungan dari penilaian siswa terhadap kegiatan ekstrakurikuler keagamaan. Selanjutnya untuk mendapatkan pemahaman yang lebih utuh dan lengkap serta pemaknaan yang mendalam terhadap kegiatan ekstrakurikuler keagamaan dilanjutkan dengan analisis secara kualitatif.

\section{HASIL DAN PEMBAHASAN}

\section{Gambaran Umum Lokasi}

Penelitian ini dilakukan di SMA Negeri 1 Mataram, Nusa Tenggara Barat (NTB). Mataram sebagai salah satu Kota di propinsi Nusa Tenggara Barat. Letaknya diapit diantara kabupaten Lombo Barat dan Selat Lombok. Pendududuk Mataram belum menyebar secara merata di seluruh wilayah Mataram. Umumnya penduduk banyak menumpuk di kecamatan Mataram. Secara rata-rata kepadatan penduduk Mataram tercatat sebesar 5,691 jiwa setiap kilometer persegi, dan wilayah terpadat adalah kecamatan Mataram dengan tingkat kepadatan 6,267 orang setiap kilometer persegi.

Kehidupan beragama yang harmonis sangat didambakan masyarakat. Hal ini terlihat dari tempat-tempat peribadatan yang ada disekitar warga seperti masjid, gereja dan lainnya. Di kota Mataram terdapat 137 buah Masjid, 150 buah Langgar, 119 buah Musholla, 17 buah Gereja, 121 buah Pura, 3 buah Vihara dan 1 buah Kelenteng.

Pada tahun 2010 penduduk menurut agama di Kota Mataram penduduk beragama Islam berjumlah 290,427 jiwa, penduduk beragama Kristen berjumlah 4,111jiwa, penduduk beragama Khatholik berjumlah 3,385 jiwa, penduduk beragama Hindu 54,676 jiwa dan penduduk beragama Budha berjumlah 4,149 jiwa.

Kota Mataram yang menjadi lokasi penelitian ini merupakan ibukota provinsi Nusa Tenggara Barat yaitu daerah dengan penduduk dari etnis Sasak, Bali, Bima, Sumbawa, Jawa, Madura, Bugis dan Minangkabau. Etnis Sasak dan Bali merupakan penduduk yang dominan jumlahnya dibandingkan etnis lainnya.

Kota Mataram dikenal pula dengan kota seribu masjid. Hampir setiap desa atau kampung terdapat masjid dan pada setiap datang/tiba waktu shalat selalu terdengar adzan. Umat Islam di kota Mataram terbilang umat yang patuh dan taat dalam menjalankan syariat. 
Kehidupan umat beragama di kota Mataram relative kondusif karena berbagai etnis yang tinggal di kota Mataram yang menganut berbagai agama dapat hidup secara aman, damai dan rukun. Bila di antara mereka ada sesuatu potensi yang akan menimbulkan dapat segera diatasi oleh pimpinan umat bersama-sama dengan pemerintah setempat.

Masyarakat kota Mataram termasuk kategori masyarakat madani, tetapi dalam pengamalan agama masih terikat dengan tradisi-tradisi keagamaan yang kental seperti halnya paham kebanyakan umat Islam di pulau Jawa.

Masyarakat kota Mataram adalah masyarakat religious, keberagaman mereka tidak perlu diragukan dalam kehidupan sehari-hari mereka termasuk kelompok yang patuh dan taat dalam melaksanakan kewajiban agamanya baik yang bersifat ibadah mahdlah seperti melaksanakan shalat lima waktu, puasa, membangun dan mendirikan madrasah, majelis taklim, masjid, pesantren dan sebagainya.

\section{Profile Responden}

\section{Pekerjaan orang tua}

Hasil pengolahan data terhadap 90 kuesioner yang kembali dari 84 kuesiner yang disebar menunjukkan bahwa, mayoritas pekerjaan orang tua (ayah) responden adalah wirausaha, sebanyak 46 orang tua atau $54,76 \%$, diikuti oleh PNS/ABRI, sebanyak 18 orang atau $21,42 \%$, petani/buruh sebanyak 9 orang atau $10.71 \%$, profesional 3 orang, atau $3,57 \%$. Sisanya sebesar 8 orang atau 9,52\%, lainnya. Selengkapnya deskripsi pekerjaan orang tua responden dapat dilihat dalam tabel 1 berikut ini.
Tabel 1. Jenis Pekerjaan Ayah Responden

\begin{tabular}{|l|l|l|l|}
\hline \multicolumn{2}{|l|}{ Jenis Pekerjaan } & Frekuensi & Prosentase \\
\hline A & PNS/ABRI & 18 & 21,42 \\
\hline B & Profesional & 3 & 3,57 \\
\hline C & Wirausaha & 46 & 54,76 \\
\hline D & Petani/Buruh & 9 & 10,71 \\
\hline E & Lainnya & 8 & 9,52 \\
\hline & Total & 84 & 100.0 \\
\hline
\end{tabular}

Berdasarkan tabel 1, di atas, mayoritas orang tua responden berprofesi sebagai wirausaha, ini menggambarkan bahwa responden berasal dari orang tua yang cukup sibukKarena sebagaimanayangdinyatakan oleh Rye (David E. Rye,1995), para wirausaha adalah individu-individu yang berorientasi kepada kerja, dan bermotivasi tinggi yang mengambil risiko dalam mengerjar tujuannya. ${ }^{6}$ Dengan perkataan lain, ayah yang berprofesi wiraswasta lebih banyak menghabiskan waktunya untuk pekerjaan dan usahannya, dan ini menyebabkan interaksi anakayah rendah. Rendahnya interaksi anakayah, sangat memungkinkan kurangnya kesempatan bagi ayah untuk memberikan pendidikan agama pada anaknya di lingkungan keluarga, padahal peran ayah sangat dominan dalam pemberian pendidikan agama pada anak-anaknya. Sedangkan untuk pekerjaan ibu, mayoritas responden sebanyak 84 orang, atau 51,19\%, menyatakan bahwa ibu mereka adalah "ibu rumah tangga", sedangkan prosentase yang terkecil 3,57\%, menyatakan bahwa 'ibu mereka', adalah petani/buruh. Selengkapnya tentang jenis pekerjaan ibu respsonden dapat dilihat pada tabel 2, berikut ini.

${ }^{6}$ David E.Rye. 1995. Tolls for Executives: The Vest Pocket Entrepreneur. Terjemahan. Prentice Hall, Inc. Englewood Cliffs, New Jersey. 
Tabel 2. Jenis Pekerjaan Ibu Responden

\begin{tabular}{|l|l|l|l|}
\hline \multicolumn{2}{|l|}{ Jenis Pekerjaan Ibu } & Frekuensi & Prosentase \\
\hline A & PNS/ABRI & 17 & 20,23 \\
\hline B & Profesional & 4 & 4,76 \\
\hline C & Wirausaha & 9 & 10,71 \\
\hline D & Petani/Buruh & 3 & 3,57 \\
\hline E & Ibu Rumah Tangga & 43 & 51,19 \\
\hline F & Lainnya & 8 & 9,52 \\
\hline & Total & 84 & 100.0 \\
\hline
\end{tabular}

Dari tabel 2, di atas selain "ibu rumah tangga", dalam jumlah yang cukup besar, yakni $20,23 \%$, pekerjaan ibu responden adalah PNS/ ABRI, diikuti oleh wirausaha, sebanyak 9 orang atau $10,71 \%$, lainnya, sebanyak 4 orang atau $4,76 \%$, berprofesi sebagai professional $=4,76 \%$. Besarnya prosentase ibu responden sebagai "ibu rumah tangga". Di satu sisi memberikan kesempatan kepada ibu untuk berinteraksi langsung dengan anaknya di rumah, dan sekaligus dapat mengisi kekurangan waktu ayah yang sibuk berwirausaha. Namun di sisi lain posisi dan peran ibu, belum menjamin bahwa, perhatian ibu terhadap anaknya tinggi.

\section{Jenjang Pendidikan Orang Tua}

Responden berdasarkan jenjang pendidikan orang tua dapat dilihat pada tabel 3. berikut ini.

Tabel 3. Jenjang Pendidikan orang tua responden

\begin{tabular}{|l|l|l|l|l|}
\hline \multirow{2}{*}{ Pendidikan Orang Tua } & \multicolumn{2}{|c|}{ Frekuensi } & \multicolumn{2}{c|}{ Prosentase } \\
\cline { 2 - 5 } & Ayah & \multicolumn{1}{c|}{ lbu } & Ayah & Ibu \\
\hline SD / MI & 15 & 14 & 17,86 & 16,67 \\
\hline SMP/MTS & 18 & 20 & 21,43 & 23,81 \\
\hline SMA/SMK/MA & 34 & 32 & 40,47 & 38,09 \\
\hline Diploma/S1/S2 & 13 & 13 & 15,47 & 15,47 \\
\hline Lainnya & 4 & 5 & 4,76 & 5,95 \\
\hline Total & 84 & 84 & 100 & 100 \\
\hline
\end{tabular}

Tabel 3, menginformasikan bahwa jenjang pendidikan orang tua responden (ayah-ibu), mayoritas SLTA, sebanyak 34 orang untuk ayah atau 40,47\%, dan 32 untuk ibu atau 38,09\%. Diikuti oleh jenjang pendidikan SLTP, masingmasing 18 orang untuk ayah, atau $21,43 \%$, dan 20 orang ibu atau $23,81 \%$. Selanjutnya pendidikan orang tuanya tamat SD/MI, masing-masing 15 orang untuk ayah, atau $17,86 \%$, dan 14 orang ibu atau $16,67 \%$. Namun demikian, cukup menggembirakan adanya orang tua responden yang berlatar belakang pendidikan diploma/ S1/S2 masing-masing 13 orang untuk ayah dan ibu, atau 15,47\%. Ini berarti, berdasarkan jenjang pendidikan orang tua (ayah-ibu), mengindikasikan bahwa mayoritas responden berasal dari keluarga dengan pendidikan yang baik (tamat SLTA).

\section{Gambaran Keberagamaan orang tua}

Dilihat dari keberagamaan orang tua responden, hasil analisis data menunjukkan bahwa, mayoritas responden berasal dari keluarga yang kurang memberikan perhatian secara optimal terhadap pengamalan ajaran agama. Hal ini dapat dilihat dari kecilnya prosentase pernyataan responden yang menyatakan; (1) keluarga mereka "sangat sering dan selalu", melakukan shalat berjamaah hanya 45 orang, atau $11,6 \%$. Mayoritas responden sebanyak 155 orang, atau 39,9\%, menyatakan bahwa 'keluarga mereka sangat jarang melaksakan shalat wajib secara berjamaah". Selengkapnya sebaran pernyataan responden, terhadap pertanyaan, pelaksanaan shalat wajib berjamaah dalam keluarga, dapat dilihat pada tabel 4 , berikut ini. 
Tabel 4. Pelaksanaan shalat wajib secara berjamaah dalam keluarga

\begin{tabular}{|c|c|c|c|c|c|c|}
\hline \multirow[b]{2}{*}{ Pernyataan } & \multirow{2}{*}{$\begin{array}{c}\text { Fre- } \\
\text { kuensi/ } \\
\text { Prosen- } \\
\text { tase }\end{array}$} & \multicolumn{5}{|c|}{ Pernyataan } \\
\hline & & SJ & J & $S$ & SS & SL \\
\hline \multirow{2}{*}{$\begin{array}{l}\text { Apakah } \\
\text { keluarga anda } \\
\text { melaksanakan } \\
\text { shalat wajib } \\
\text { secara } \\
\text { berjamaah? }\end{array}$} & $f$ & 35 & 29 & 12 & 6 & 2 \\
\hline & $\%$ & 41,67 & 34,52 & 14,28 & 7,14 & 2,38 \\
\hline
\end{tabular}

Indikasi selanjutnya tentang rendahnya kualitas keberagamaan keluarga responden tergambar dari rendahnya frekuensi membaca al-Qur'an di rumah. Hasil tabulasi data, mendapatkan bahwa mayoritas responden sebanyak 35 orang, atau $41,67 \%$, menyatakan mereka di rumah jarang membaca Al-Qur'an. Dan dalam jumlah yang besar juga, sebesar $34,52 \%$, atau 29 responden, menyatakan membaca Al-Qur'an di rumah, sangat jarang. Hanya 20 orang atau $23,80 \%$, responden yang menyatakan keluarga mereka "sangat sering dan selalu" membaca Al-Qur'an, di rumah.

Tabel 5. Frekuensi membaca Al-Qur'an dalam keluarga

\begin{tabular}{|c|c|c|c|c|c|c|}
\hline \multirow[b]{2}{*}{ Pernyataan } & \multirow{2}{*}{$\begin{array}{c}\text { Fre- } \\
\text { kuensi/ } \\
\text { Prosen- } \\
\text { tase }\end{array}$} & \multicolumn{5}{|c|}{ Pernyataan } \\
\hline & & SJ & $\mathrm{J}$ & $S$ & SS & $\mathrm{SL}$ \\
\hline \multirow{2}{*}{$\begin{array}{l}\text { Apakah } \\
\text { keluarga anda } \\
\text { membaca } \\
\text { Al Qur'an di } \\
\text { rumah? }\end{array}$} & f & 27 & 35 & 12 & 8 & 2 \\
\hline & $\%$ & 32,14 & 41,66 & 14,28 & 9,52 & 2,38 \\
\hline
\end{tabular}

Untuk pertanyaan, apakah orang tua mereka mengikuti pengajian keagamaan di masjid/musholla dekat tempat tinggal mereka dapat dilihat pada tabel 6, berikut ini.
Tabel 6. Kehadiran orang tua mengikuti pengajian di masjid/mushalla

\begin{tabular}{|c|c|c|c|c|c|c|}
\hline \multirow[b]{2}{*}{ Pernyataan } & \multirow{2}{*}{$\begin{array}{c}\text { Frekuensi/ } \\
\text { Prosen- } \\
\text { tase }\end{array}$} & \multicolumn{5}{|c|}{ Pernyataan } \\
\hline & & SJ & $J$ & $S$ & SS & $\mathrm{SL}$ \\
\hline \multirow{2}{*}{$\begin{array}{l}\text { Apakah orang } \\
\text { tua (ayah/ibu ) } \\
\text { anda mengikuti } \\
\text { pengajian } \\
\text { di masjid / } \\
\text { musholla / } \\
\text { majlis taklim }\end{array}$} & $f$ & 14 & 42 & 7 & 5 & 16 \\
\hline & $\%$ & 16,66 & 50 & 8,33 & 5,95 & 19,05 \\
\hline
\end{tabular}

Berdasarkan tabel di atas, mayoritas siswa sebesar 42 orang, atau 50\%, menyatakan orang tua mereka "jarang" mengikuti pengajian di masjid/mushalla/ majlis taklim. Sebanyak $16,66 \%$, atau 14orang menyatakan "sangat jarang". Dengan demikian 66,66\%, responden menyatakan orang tua mereka "sangat jarang dan jarang", mengikuti pengajian di masjid/musholla dimana mereka tinggal. Sedangkanjumlah respondenyang menyatakan orang tua mereka "sangat sering, dan selalu", mengikuti pengajian, hanya 21 orang atau $25 \%$, dan 7 orang atau $8,33 \%$ orang tua mereka mengikuti pengajian di masjid/mushalla/ majlis taklim "Sedang". Boleh jadi rendahnya kegiatan orang tua untuk menghadiri pengajian, berkaitan dengan kesibukan orang tua dalam memenuhi kebutuhan keluarga, disebabkan faktor ekonomi.

Aspek selanjutnya, dari latar belakang keagamaan orang tua, adalah tentang apakah orang tua mereka mengingatkan/menyuruh untuk shalat ketika waktu shalat tiba. Pernyataan selengkapnya dapat dilihat pada tabel 7, berikut ini. 
Tabel 7. Perhatian orang tua mengingatkan shalat

\begin{tabular}{|c|c|c|c|c|c|c|}
\hline & \multirow{2}{*}{$\begin{array}{c}\text { Fre- } \\
\text { kuensi/ }\end{array}$} & \multicolumn{5}{|c|}{ Pernyataan } \\
\cline { 3 - 7 } & $\begin{array}{c}\text { Prosen- } \\
\text { tase }\end{array}$ & SJ & J & S & SS & SL \\
\hline $\begin{array}{l}\text { Apakah } \\
\text { orang tua } \\
\text { mengingatkan / } \\
\text { menyuruh anda } \\
\text { untuk shalat, } \\
\text { ketika waktu } \\
\text { shalat tiba, }\end{array}$ & $\mathrm{f}$ & 32 & 29 & 13 & 8 & 2 \\
\cline { 3 - 7 } & & 38,10 & 34,52 & 15,48 & 9,52 & 2,38 \\
\hline
\end{tabular}

Sebagaimana tabel 7, di atas, frekuensi orang tua yang "sangat-sering dan selalu", mengingatkan anaknya untuk melaksanakan shalat sangat rendah, yaitu, 10 orang atau $11,9 \%$. Disisi lain mayoritas responden, menyatakan bahwa orang tua mereka, "sangat-jarang, dan "jarang", untuk mengingatkan mereka agar shalat, yaitu, $38,10 \%$, dan $34,52 \%$, atau 32 orang dan 29 orang. Ini bertentangan dengan ajaran Islam yang mengajarkan agar orang tua menyerukan shalat pada anak-anaknya ketika mereka usia tujuh tahun dan diperintahkan untuk memukulnya jika mereka membangkang atau meninggalkan shalat. Pernyataan ini ternyata selaras dengan pernyataan terhadap pertanyaan sebelumnya, terutama berkenaan dengan pelaksanaan shalat berjamaah di rumah, yang sangat rendah frekuensinya.

\section{Aktifitas Ekstra Kurikuler Keagamaan}

Para guru dan orang tua murid di lingkungan SMA di kota Mataram menyadari betul bahwa jam pelajaran pendidikan agama Islam hanya diberikan 2 jam pelajaran tiap minggu dirasakan sangat minim, sedangkan tujuan pendidikan agama Islam adalah agar para siswa menjadi manusia yang beriman, bertaqwa dan berakhlakul karimah. Sehubungan dengan ini, para pimpinan di kalangan SMA Negeri 1 Mataram memberikan perhatian yang besar terhadap penyelenggaraan pembinaan keagamaan di luar jam pendidikan agama yang telah terjadwal dua jam perminggu. Pelaksanaan pembinaan agama tersebut ditangani oleh para guru agama dan dibantu oleh guru bidang studi lain yang dipilih oleh Kepala Sekolah, antara lain guru Bimbingan dan Konseling serta guru IPS dan sebagainya.

Kegiatan pesantren kilat ini melibatkan semua sumber daya manusia yang ada di SMA tersebut dengan sasaran kepada para siswa. Panitia pelaksananya adalah para guru dan karyawan. Setelah itu, maka pada tahuntahun berikutnya sampai saat ini SMA Negeri 1 secara terus menerus menyelenggarakan pesantren tersebut. SMA Negeri 1 terdapat tempat ibadah, musholla yang cukup memadai, sekalipun belum dapat menampung semua siswa secara bersama. Fasilitas untuk kegiatan Rohani Islam dalam konteks ektrakurikuler keagamaan selain selain masjid dengan segala kelengkapannya seperti loud speaker, bukubuku bacaan, alas sembahyang, juga disediakan pula satu kelas khusus yang didesain untuk pendalaman keagamaan baik di SMA Negeri 1. Menurut para Pembina Imtaq, SMA Negeri 1 Mataram untuk meningkatkan iman dan taqwa para murid pada khususnya dan masyarakat lingkungan sekolah pada umumnya. Para Pembina Imtaq menyatakan secara spesifik tujuan pembinaan Imtaq di SMA Negeri 1 Mataram adalah :

1. Membina generasi muslim yang beriman dan bertaqwa serta berpengetahuan dalam memimpin bangsa di hari depan;

2. Menciptakan lingkungan yang Islami di sekolah, sehingga dengan demikian peserta dapat memahami hak dan kewajibannya dalam berbangsa, bernegara dan beragama;

3. Menciptakan siswa yang santun terhadap diri sendiri dan orang lain;

4. Menciptakan suasana saling menghormati antar umat beragama, sehingga mampu menanggulangi disintegrasi bangsa.

Pembinaan Imtaq di SMA Negeri 1 Mataram diarahkan agar setiap murid dapat membaca al Quran dengan baik dan benar; dan memperdalam dan mengembangkan materi pelajaran agama di sekolah yang 
diberikan di kelas. Oleh karena itu bentuk kegiatan pengembangan bermacam-macam. Bentuk-bentuk kegiatan tersebut antara lain seperti kegiatan Imtaq hari Jumat pagi pada setiap minggu, kegiatan shalat Dhuha yang dilakukan pada setiap hari pada jamjam istirahat, kegiatan peringatan hari-hari besar Islam seperti Maulid Nabi, Tahun Baru Islam, 1 Muharram, Isra' Mi'raj, peringatan hari besar Islam bersamaan dengan tanggal dan bulan terkait. Patut dicatat di sini bahwa penyelenggaraan kegiatan tersebut memang hanya terbatas bagi murid-murid, guru dan karyawan sekolah saja. Karena sifat kegiatan ini memang internal saja. Pelibatan unsure luar terbatas pada penceramah dan tidak setiap saat.

Materi pembinaan Imtaq yang dilakukan pada hari Jumat pagi adalah keimanan, akhlak dan tarikh Islam. Selain itu tentu saja al Quran dan al Hadist Nabi. Materi-materi tersebut dalam penyampaiannya dikemas dalam bentuk materi ceramah yang disampaikan oleh para Pembina Imtaq dan para siswa di sekolah tersebut.

Adapum metode yang digunakan dalam penyelenggaraan Imtaq baik di SMA Negeri 1 Mataram pada umumnya disesuaikan dengan substansi dan materi pembinaan. Namun secara umum di kedua sekolah tersebut mempergunakan metode ceramah. Metode ini dianggap cocok karena materi pembinaan umumnya diambil dari al Quran dan al Hadis tsebagai dasara untuk mengupas berbagai masalah social dan kemasyarakatn (mu'amalah). Metode lain yang dipergunakan dalam pembinaan Imtaq antara lain metode pengawasan, metode kunjungan, outbond, metode menirukan (untuk baca tulis al Quran).

Pelaksanaan evaluasi ektrakurikuler dilakukan oleh para Pembina Imtaq dan Kepala Sekolah terhadap semua bentuk kegiatan ektrakurikuler keagamaan. Sasran evaluasi adalah pada program Imtaq, tingkat capaian program, tingkat kehadiran peserta dan output program bagi sekolah dan murid.
Evaluasi tersebut dilakukan bersifat umum, criteria penilaiannya tidak ketata seperti halnya penyelenggaraan ujian sekolah. Dalam ujian sekolah ada outputnya yaitu siswa lulus atau tidak lulus. Nilainya baik, buruk, baik sekali, cukup atau buruk sekali. Dalam penilaian tersebut dilihat secara umum bagaimana program itu berjalan atau tidak sesuai dengan agenda sekolah, sejauh mana capaian program, tingkat kehadiran siswa dan sejauh mana program ekstrakurikuler dapat mendukung dan memperkaya pendidikan agama di sekolah.

Kegiatan penilaian itu dilakukan secara periodik, per triwulan dan dilakukan terhadap setiap kegiatan ekstrakurikuler keagamaan. Dari hasil evaluasi tersebut pada akhir tahun ajaran Pembina imtaq mengkompilasi evaluasi tersebut menjadi evaluasi. Sebagai pelaksanaan penilaian adalah para guru Bimbingan dan Konseling dan dipimpin oleh Kepala Sekolah. Hasil dari penilaian adalah sebagai bahan penyempurnaan bagi penyelenggaraan Imtaq tahun berikutnya.

Sumber belajar yang dipergunakan dalam pembinaan Imtaq di SMA Negeri 1 Mataram adalah buku-buku yang dianjurkan di dalam kurikulum pendidikan agama dan tentu dikembangkan dengan sumber-sumber lain.

Sumber belajar utama pembinaan Imtaq adalah al Quran dan al Hadist, di samping tafsir, buku fiqih, buku tauhid, buku sejarah dan Tarikh Islam. Secara lebih spesifik bukubuku yang menjadi sumber belajar antara lain :

a) Al Quran dan terjemahnya terbitan Kementerian Agama;

b) Terjemahan ringkasan Shahih Buchori;

c) Terjemahan ringkasan Shahih Muslim;

d) Tuntunan Shalat;

e) Tuntunan Dzikir dan Doa;

f) Pedoman Pendidikan Agama Islam untuk SMA terbitan Kementerian Agama. 
Sedangkan sumber lain yang sifatnya popular dan actual diambil dari media massa dan media on line yang tersedia di sekolah.

\section{Motivasi siswa dalam kegiatan Ekstrakurikuler}

Beragam faktor yang mendorong siswa SMA mengikuti kegiatan ekstra-kurikuler keagamaan. Berdasarkan pernyataan responden, factor-faktor tersebut dapat dikelompokkan menjadi dua, yaitu, (a) internal, dan (b) eksternal. Faktor internal, antara lain; motif keagamaan, motif sosial, dan motif pribadi. Sedangkan faktor eksternal, berkenaan dengan kegiatan ekstra-kurikuler keagamaan itu sendiri, seperti; program, materi, metode, pembimbing, dan dorongan guru.

Berikut ini akan dibahas masing-masing faktor yang mendorong seseorang ikut kegiatan ekstra-kurikuler keagamaan.

\section{Faktor Internal " motif keagamaan"}

Untuk mengetahui apakah motif keagamaan merupakan salah faktor yang menyebabkan responden ikut dalam kegiatan ekstrakurikuler keagamaan, dibuat pernyataan sebagai berikut; " bahwa kegiatan rohis, dapat meningkatkan pemahaman agama". Terhadap pernyataan ini, mayoritas responden 32 orang, atau $38,09 \%$, menyatakan "sangat setuju", diikuti oleh 25 orang atau 29,76\%, yang menyatakan " setuju". Ini berarti mereka mengiyakan, bahwa dengan mengikuti kegiatan rohis, dapat meningkatkan pemahaman agama. Yang memilih alternatif pernyataan " tidak setuju, dan sangat tidak setuju", berjumlah 15 orang atau $17,85 \%$, Selengkapnya dapat dilihat pada tabel 8 berikut ini.
Tabel 8. Penilaian responden terhadap kegiatan rohis

\begin{tabular}{|c|c|c|c|c|c|c|}
\hline \multirow{2}{*}{ Pernyataan } & \multirow{2}{*}{$\begin{array}{l}\text { Frekuensi/ } \\
\text { Prosentase }\end{array}$} & \multicolumn{5}{|c|}{ Pernyataan } \\
\hline & & SS & $S$ & KS & TS & STS \\
\hline \multirow{2}{*}{$\begin{array}{l}\text { Dengan } \\
\text { mengikuti } \\
\text { kegiatan Rohis } \\
\text { pemahaman } \\
\text { saya terhadap } \\
\text { ajaran-ajaran } \\
\text { Islam makin } \\
\text { mendalam }\end{array}$} & $f$ & 32 & 25 & 12 & 10 & 5 \\
\hline & $\%$ & 38,09 & 29,76 & 14,28 & $\mid 11,90$ & 5,95 \\
\hline
\end{tabular}

Untuk mengetahui konsistensi "reliabilitas" pernyataan responden terhadap pernyataan sebagaimana tabel 9, dilanjutkan dengan pernyataan sebagai berikut "Kegiatan ekstrakurikulerkeagamaan, kurangcocokdigunakan sebagai salah satu cara dalam menanamkan nilai-nilai ke imanan?" Terhadap pernyataan ini, mayoritas responden sebanyak 27 orang atau $32,14 \%$, "sangat tidak setuju", dengan pernyataan tersebut, dan 21 orang atau 25\%, menyatakan " tidak setuju". Yang menjawab "sangat setuju dan setuju" hanya 19 orang atau $22,61 \%$. Hal ini berarti pernyataan responden sama dengan pernyataan sebelumnya "reliabel" bahwa "kegiatan ekstrakurikuler keagamaan, dapat meningkatkan pemahaman agama". Apa yang diberikan pada kegiatan ekstrakurikuler keagamaan merupakan program pengayaan yang dilakukan oleh guru kepada siswanya untuk melengkapi kekurangan pada pendidikan agama yang diajarkan di kelas. Jika di kelas lebih banyak memberikan kerangka teoritik tentang materi-materi keislaman, maka pada kegiatan ekstrakurikuler ini lebih bersifat praktis-aplikatif, sehingga terdapat kesinambungan seluruh program sekolah. Selengkapnya pernyataan responden, dapat dilihat pada tabel 9 , berikut ini. 
Tabel 9. Tanggapan responden terhadap manfaat ekstrakurikuler keagamaan

\begin{tabular}{|c|c|c|c|c|c|c|}
\hline \multirow{2}{*}{ Pernyataan } & \multirow{2}{*}{$\begin{array}{l}\text { Frekuensi/ } \\
\text { Prosentase }\end{array}$} & \multicolumn{5}{|c|}{ Pernyataan } \\
\hline & & SS & $S$ & KS & TS & STS \\
\hline \multirow{2}{*}{$\begin{array}{l}\text { Kegiatan } \\
\text { ekstrakurikuler } \\
\text { keagamaan, } \\
\text { kurang cocok } \\
\text { digunakan seba } \\
\text { gai salah satu cara } \\
\text { dalam menanam } \\
\text { kan nilai-nilai ke } \\
\text { imanan? }\end{array}$} & $f$ & 4 & 15 & 17 & 21 & 27 \\
\hline & $\%$ & 4,76 & 17,85 & 20,23 & 25 & 32,14 \\
\hline
\end{tabular}

Selanjutnya untuk mengetahui motif sosial, dan motif pribadi, penyebab seseorang mengikuti kegiatan ekstrakurikuler keagamaan, disusun pernyataan sebagaimana tampak dalam tabel 10. Pada tabel tersebut nampaknya sekaligus mendukung pernyataan responden sebelumnya, bahwa kuatnya keinginan responden mengikuti eksktrakurikuler keagamaan untuk lebih mendalami dan meningkatkan pemahaman terhadap ajaran agamanya.

Tabel 10 Tanggapan responden terhadap kegiatan ekstrakurikuler keagamaan

\begin{tabular}{|l|c|c|c|c|c|c|}
\hline \multirow{2}{*}{ Pernyataan } & \multirow{2}{*}{$\begin{array}{l}\text { Frekuensi// } \\
\text { Prosentase }\end{array}$} & SS & S & KS & TS & STS \\
\hline $\begin{array}{l}\text { Kegiatan Rohis } \\
\text { bermanfaat bagi } \\
\text { pengembangan } \\
\text { diri pribadi }\end{array}$ & $\mathrm{f}$ & 33 & 27 & 1 & 13 & 10 \\
\cline { 2 - 7 } $\begin{array}{l}\text { Mengikuti } \\
\text { kegiatan } \\
\text { ekstrakurikuler } \\
\text { keagamaan, } \\
\text { dapat } \\
\text { mengembangkan } \\
\text { sikap sosial } \\
\text { seseorang }\end{array}$ & $\%$ & 39,28 & 32,14 & 1,19 & 15,48 & 11,90 \\
\cline { 2 - 7 } & 40 & 23 & 3 & 12 & 6 \\
\hline
\end{tabular}

Pada tabel 10, mengungkap motif sosial, dan motif pribadi, yang merupakan faktor internal, menyebabkan seseorang siswa mengikuti kegiatan ekstrakurikuler keagamaan untuk mengembangkan sikap sosial siswa $(47,62 \%)$. Ini berarti bahwa yang mendorong siswa mengikuti kegiatan ekstra kurikuler keagamaan karena keiginan mereka untuk dapat mengembangkan sikap sosial bagi lingkungannya dan dalam rangka mengembangkan, mendalami serta meningkatkan pemahaman mereka terhadap agamanya.

\section{Faktor Eksternal}

Faktor eksternal, yang mendorong siswa mengikuti kegiatan ekstra-kurikuler, adalah kegiatan ekstra-kurikuler itu sendiri, yang meliputi; metode, materi, pembimbing, serta, pergaulan. Data dalam tabel 11, di bawah merupakan rangkuman pernyataan responden terhadap manfaat kegiatan ekstrakurikuler keagamaan, kaitannya dengan faktor eksternal.

Tabel 11. Pernyataan responden terhadap ekstrakurikuler Keagamaan

\begin{tabular}{|c|c|c|c|c|c|c|}
\hline \multirow{2}{*}{ Pernyataan } & \multirow{2}{*}{$\begin{array}{l}\text { Frekuensi/ } \\
\text { Prosentase }\end{array}$} & \multicolumn{5}{|c|}{ Pernyataan } \\
\hline & & SS & $S$ & KS & TS & STS \\
\hline \multirow{2}{*}{$\begin{array}{l}\text { Saya mengikuti } \\
\text { kegiatan Rohis, } \\
\text { karena metode } \\
\text { yang digunakan } \\
\text { menarik? }\end{array}$} & $f$ & 39 & 19 & 14 & 8 & 4 \\
\hline & $\%$ & 46,43 & 22,62 & 16,67 & 9,52 & 4,76 \\
\hline \multirow{2}{*}{$\begin{array}{l}\text { Saya mengikuti } \\
\text { kegiatan } \\
\text { Rohis karena } \\
\text { materinya } \\
\text { bermanfaat } \\
\text { untuk } \\
\text { kehidupan } \\
\text { sosial }\end{array}$} & f & 40 & 20 & 15 & 8 & 1 \\
\hline & $\%$ & 47,62 & 23,81 & 17,86 & 9,52 & 1,19 \\
\hline \multirow{2}{*}{$\begin{array}{l}\text { Saya } \\
\text { menyenangi } \\
\text { kegiatan } \\
\text { Rohis, karena } \\
\text { pembim- } \\
\text { bingnya yang } \\
\text { berkualitas }\end{array}$} & f & 37 & 22 & 13 & 6 & 6 \\
\hline & $\%$ & 44,04 & 26,19 & 15,48 & 7,14 & 7,14 \\
\hline \multirow{2}{*}{$\begin{array}{l}\text { Saya } \\
\text { menyenangi } \\
\text { kegiatan Rohis, } \\
\text { karena dapat } \\
\text { bergaul dengan } \\
\text { teman di kelas } \\
\text { lain }\end{array}$} & f & 39 & 18 & 11 & 12 & 4 \\
\hline & $\%$ & 46,43 & 21,43 & 13,09 & 14,28 & 4,76 \\
\hline
\end{tabular}


Pada tabel 11 terdapat 4 pernyataan pendapat responden berkenaan dengan faktor eksternal, yang mendorong seseorang mengikuti kegiatan ekstra-kurikuler keagamaan. Secara hierarki pernyataan responden, "sangat setuju", berkenaan dengan keikutsertaannya dalam kegiatan ekstrakurikuler keagamaan adalah karena; (1) materi ekstrakurikuler keagamaan yang bermanfaat $(47,62 \%), \quad(2)$ metode yang digunakan menarik (46,43\%), (3) demi pergaulan (46,43\%), dan (4) pembimbing yang berkualitas $(44,04 \%)$. Prioritas pertama seseorang mengikuti kegiatan ekstrakurikuler keagamaan, adalah karena "materi ekstrakurikuler keagamaan yang bermanfaat", pernyataan ini relevan dengan pernyataan responden terhadap pernyataan sebelumnya, di mana responden tertarik mengikuti kegiatan ekstrakurikuler keagamaan, karena faktor internal. Kemungkinan lain, kenapa responden menyatakan, keikutsertaannya terhadap kegiatan ekstrakurikuler keagamaan, karena "materi ekstrakurikuler" boleh jadi karena responden, menyadari bahwa mereka berasal dari keluarga yang kurang memberikan perhatian secara optimal terhadap pengamalan ajaran agama. Prioritas kedua, bahwa seseorang mengikuti kegiatan ekstrakurikuler keagamaan, karena metode yang digunakan menarik, boleh jadi ini mengindikasikan bahwa pelajaran agama yang diberikan oleh guru di sekolah, kurang variatif, baik metode yang digunakan maupun materi yang disampaikan. Pembelajaran agama Islam yang diberikan guru dalam kelas kurang menjawab kebutuhan siswa, dan tidak konstekstual. Artinya, materi pendidikan agama di sekolah lebih menekankan hal-hal yang bersifat teori-normatif, kurang dikaitkan dengan pengalaman dan kondisi sehari-hari. Prioritas ketiga, kenapa seseorang aktif mengikuti kegiatan ekstrakurikuler keagamaan, adalah demi pergaulan. Pernyataan ini sesuai dengan taraf perkembangan siswa, yakni remaja cenderung suka bergaul. Prioritas keempat, adalah faktor pembimbing yang berkualitas. Sedangkan prioritas keempat adalah karena pembimbingnya yang berkualitas. Ini berarti keikutsertaan mereka terhadap kegiatan ekstrakurikuler keagamaan, lebih karena keinginan sendiri kurang melihat pada kualitas pembimbingan.

\section{Kerjasama Sekolah, Orang Tua dan Lembaga Keagamaan dalam Kegiatan Ekstra Kurikuler}

Bentuk lain dari kepeduliaan orang tua, terhadap pendidikan agama di sekolah, adalah hampir semua sekolah memiliki Masjid/ Musholla, yang dibangun dengan swadaya sekolah, dalam hal ini adalah donasi para orang tua. Setiap kegiatan pesantren kilat, hampir tidak ada orang tua yang melarang anaknya ikut Sanlat.

Secara institusi lembaga keagamaan tidak begitu nampak peranannya dalam kegiatan ekstrakurikuler keagamaan yang dilakukan oleh sekolah, meskipun demikian secara pribadi-pribadi, banyak tokoh masyarakat yang ikut membina dan terlibat dalam kegiatan ekstrakurikuler keagamaan di sekolah-sekolah. Keterlibatan para tokoh agama tersebut, adalah dalam bentuk, memberikan ceramah agama, sebagai narasumber dalam seminar dan talk-show.

Kesadaran para kepala sekolah, guru agama, dan para orang tua, akan sangat sedikitnya waktu bagi pembelajaran agama Islam, menyebabkan kuatnya dorongan dan perhatian terhadap kegiatan ekstrakurikuler keagamaan yang dilakukan oleh para pengurus Rohis. Perhatian para orang tua, dan masyarakat sekitar, diwujudkan dalam bentuk penyediaan fasilitas pendidikan agama, seperti; membangun masjid/musholla, dan iuaran lainnya.

\section{PENUTUP}

\section{Kesimpuan}

1. Aktifitas ekstrakurikuler PAI SMAN 1 Mataram dilakukan melalui kegiatan harian, mingguan, semester, dan tahunan. Kegiatan ekstrakurikuler yang bersifat 
harian antara lain adalah membaca AlQur'an pada awal jam pelajaran, sholat dzuhurbersama, danberdo'abersama-sama dalam memulai dan mengakhiri pelajaran. Kegiatan ekstrakurikuler keagamaan yang bersifat minggunan antara lain adalah: sholat jum'at bersama, mengenakan buasana muslim/muslimah, pengumpulan infaq/sadaqah "kotak amal". .Kegiatan ekstrakurikuler yang bersifat semesteran adalah: cerdas cermat, penyelenggaraan, pendalaman agama dibimbing alumni, tadabur alam. Kegiatan ekstrakurikuler yang bersifat tahunan antara lain adalah: kegiatan berbuka bulan ramadhan, pengumpulan dan pembagian zakat, pelaksanaan pesantren kilat, pemotongan hewan Qurban, serta menyelenggarakan kegiatan "pada peringatan hari-hari besar Islam (PHBI)", seperti, peringatan Maulid Nabi, Isra' Mi'raj.

2. Terdapat dua faktor utama yang berpengaruh terhadap keikutsertaan siswa dalam program ekstrakurikuler keagamaan, yaitu; (a) internal, dan (b) eksternal. Faktor internal, antara lain; motif keagamaan, motif sosial, dan motif pribadi. Sedangkan faktor eksternal, berkenaan dengan kegiatan ekstrakurikuler keagamaan itu sendiri, seperti; program, materi, metode, pembimbing, dan dorongan guru.

3. Secara umum terbina kerjasama yang positif antara sekolah, orang tua, dan lembaga keagamaan, serta pemerintah daerah. Kerjasama yang baik ini, boleh jadi karena para orang tua menyadari bahwa, sesuai dengan perkembangan pembangunan, perkembangan IPTEK, anak-anak mereka perlu dibentengi dengan nilai-nilai agama, serta keimanan yang baik. Bentuk kepeduliaan orang tua, terhadap pendidikan agama di sekolah, adalah hampir semua sekolah memiliki Masjid/ Musholla, dibangun dengan swadaya sekolah, dalam hal ini adalah donasi para orang tua. Setiap kegiatan pesantren kilat, hampir tidak ada orang tua yang melarang anaknya ikut Sanlat. Keterlibatan para tokoh agama tersebut, adalah dalam bentuk, memberikan ceramah agama,

\section{Rekomendasi}

1. Sekolah perlu mendorong terjalinnya hubungan antara Rohis sebagai penyelenggara kegiatan ekstrakurikuler keagamaan dengan organisasi-organisasi keagamaan konvensional

2. Sekolah perlu menjalin hubungan yang lebih intensif dengan orang tua siswa agar terbentuk sinergi antara pendidikan agama di sekolah dengan pendidikan keagamaan di keluarga untuk lebih mengoptimalkan pendalaman keagamaan siswa bagi peningkatan imtaq dan akhlak.

3. Pemerintah, dalam hal ini Kementerian Agama, agar membuat panduan yang lebih standar tentang ragam kegiatan ekstrakurikuler keagamaan di sekolah, dengan memperhatikan keragaman setting sosial keagamaan dan budaya masyarakat setempat.

\section{SUMBER BACAAN}

Ali M. Asrori. 2008. Psikologi Perkembangan Peserta didik. Jakarta: Bumi Aksara.

David E.Rye. 1995. Tolls for Executives: The Vest Pocket Entrepreneur. Terjemahan. Prentice Hall, Inc. Englewood Cliffs, New Jersey.

Suharsimi, Arikunto. 2006. Prosedur Penilaian Suatu Pendekatan Praktik. Jakarta: Bumi Aksara

http://smanbergas.sch.id,2008:online

http://ariefyuri.blogspot.com/2009/03/ pentingnya-kegiatan-ekstrakurikuler. html

Zamroni. 2000. "Paradigma Pendidikan Masa Depan". Jakarta: Bigraf PublishinG 